М.В. Кас'яненко ${ }^{1}$, В.А. Маляр ${ }^{1}$, Є.А. Бондар ${ }^{1}$, М.А. Павленко ${ }^{2}$

${ }^{1}$ Начіональний університет оборони Украӥни ім. I. Черняховського, Київ

${ }^{2}$ Харківський національний університет Повітряних Сил ім. І. Кожедуба, Харків

\title{
МЕТОДИКА ОЦІНЮВАННЯ СТІЙКОСТІ СИСТЕМИ ЗВ'ЯЗКУ, РАДІОТЕХНІЧНОГО ЗАБЕЗПЕЧЕННЯ ТА АВТОМАТИЗАЦІЇ УПРАВЛІННЯ ПОВІТРЯНОГО КОМАНДУВАННЯ
}

\begin{abstract}
Аналіз досвіду війн та збройних конфліктів свідчить про те, щэо максимальна реалізація бойових можливостей повітряного командування багато у чому залежить від наявності стійкого, безперервного, оперативного та скритого управління. Таке управління може бути досягнуте лише при побудові високоефективної, багаторівневої системи управління, функціонування якої, об'єктивно, залежить від ефективності функціонування підсистеми зв'язку, радіотехнічного забезпечення та автоматизації управління. Проте, досвід застосування сил та засобів зв'язку, РТЗ, А та ІС повітряного командування в ході антитерористичної операчії на сході України свідчить про те, щзо система зв'язку, радіотехнічного забезпечення та автоматизачї управління внаслідок ряду причин, не в повній мірі задовольняє потреби органів управління. Серед таких причин, основною слід вважати - ї̈ недостатню стійкість. Тому, виникає нагальна потреба у проведенні наукових досліджень з метою забезпечення ї̈ стійкості на необхідному рівні. Питанню оцінювання стійкості системи зв'язку, радіотехнічного забезпечення та автоматизації управління присвячено ряд наукових праць. Проте їх аналіз показав, щзо вони, з тих чи іниих причин, не можуть бути в повній мірі використані для оцінювання стійкості системи зв'язку, радіотехнічного забезпечення та автоматизації управління в сучасних умовах ведення бойових дій. У статті запропоновано методику, яка на відміну від відомих, трунтується на методі еквівалентних топологічних перетворень, що дозволило більш адекватно описати процес функціонування системи в сучасних умовах ведення бойових дій. Розроблення даної методики проведено з обтрунтуванням моделі системи, визначення обмежень та порядку підготовки вихідних даних. Представлено алгоритм очінювання стійкості інформачійних напрямків за визначеними показниками та критеріями. Сформульовані пропозиції щчодо практичної реалізації розробленої методики у вигляді спеціалізованого програмного забезпечення. Окреслені перспективи подальших досліджень. Основними методами дослідження, які використані при його проведенні були методи аналізу, синтезу та еквівалентних топологічних перетворень.
\end{abstract}

Ключові слова: система зв'язку, радіотехнічне забезпечення та автоматизація управління, стійкість системи зв'язку, радіотехнічного забезпечення та автоматизації управління, живучість системи зв'язку, радіотехнічного забезпечення та автоматизації управління, інформаційний напрямок, вузол зв'язку, лінія зв'язку.

\section{Вступ}

Постановка проблеми. Бойові дії повітряних командувань (ПвК) у антитерористичній операції (ATO) на Сході України яскраво показали недоліки системи зв’язку, радіотехнічного забезпечення та автоматизації управління (С3, РТЗ та АУ). Виявлені недоліки обумовлені, перш за все, тим, що для ii побудови були використані застарілі, в більшості аналогові засоби зв'язку, радіотехнічного забезпечення та автоматизації управління. Ці засоби вже не відповідають вимогам не тільки можливих великомасштабних війн, але й сучасних війн малої інтенсивності та не дозволяють максимально реалізувати потенційні можливості систем управління повітряного командування.
Тому керівництвом держави було прийнято рішення про закупівлю, розробку та прийняття на озброєння новітніх зразків засобів зв’язку, радіотехнічного забезпечення та автоматизації управління. Завдяки цьому С3, РТЗ та АУ, яку розгортають сили і засоби військових частин (підрозділів) зв'язку та радіотехнічного забезпечення (зв’язку), з кожним роком осучаснюється (оцифровується). Проте, закупівля та розгортання новітніх засобів телекомунікації, а відповідно, і переведення існуючої С3, РТЗ та АУ на цифрові засоби відбувається, як правило, на основі знань та досвіду окремих службових осіб, без застосування наукових методів для оцінювання іiі стійкості в різних умов обстановки. Такий підхід може призвести до значних проблем під час бойового застосування С3, РТЗ та АУ. 
Аналіз останніх досліджень і публікацій. На сторінках фахових видань неодноразово висвітлювалися методики оцінювання стійкості С3, РТ3 та АУ. Проте, проведений аналіз показав, що найбільш розповсюджені методики були відпрацьовані у 8090-х роках XX століття науковцями та викладачами Військової академії зв'язку і вже не відповідають умовам сьогодення [1-4].

Вивчення та аналіз більш сучасної науковотехнічної літератури [5-8] за цією тематикою дозволяє зробити висновок, що запропоновані в них методики не враховують низки факторів, які значно впливали та впливають на стійкість С3, РТЗ та АУ в ході проведення АТО (ООС). Все це обумовлює необхідність удосконалення наявних методик оцінювання стійкості С3, РТЗ та АУ.

Мета статті. В даній статті авторами запропонована методика оцінювання стійкості С3, РТ3 та АУ, яка грунтується на методі еквівалентних топологічних перетворень і враховує фактори, які є притаманними сучасним бойовим діям.

\section{Виклад основного матеріалу}

Відповідно до вимог керівних документів, стійкість $є$ однією з вимог, які висуваються до С3, РТЗ та АУ. Стійкість - це здатність С3, РТЗ та АУ виконувати завдання в умовах впливу різноманітних факторів. Стійкість С3, РТЗ та АУ є інтегральною вимогою і включає в себе живучість, надійність, завадостійкість та кіберстійкість [9].

Виходячи з вищезазначеного кількісним показником оцінювання стійкості С3, РТЗ та АУ, в статті прийнято імовірність того, що система буде виконувати завдання в умовах впливу різноманітних факторів в будь-який випадково обраний момент часу $P_{c}$.

$$
P_{c}=P_{\mathscr{N}} P_{H} P_{3} P_{\kappa},
$$

де $P_{\varkappa}$ - імовірність функціонування С3, РТЗ та АУ в умовах вогневого впливу (показник живучості);

$P_{H}$ - імовірність справної роботи С3, РТЗ та АУ (показник надійності);

$$
P_{3} \text { - імовірність не подавлення С3, РТЗ та АУ }
$$

(показник завадостійкості);

$P_{\kappa}$ - імовірність функціонування в умовах кібернетичного впливу (показник кіберстійкості).

Однак враховуючи те, що для обміну повідомленнями між пунктами управління будь-якої системи управління військами (силами), в тому числі, і в системі управління ПвК організуються інформаційні напрямки (IН), які можуть суттєво відрізнятися один від одного, що необхідно враховувати при оцінюванні стійкості С3, РТЗ та АУ, а саме:

- на кожному IH, виходячи 3 прийнятого порядку управління військами (силами), обсягу і тер- міновості інформації, що передається, наявності сил і засобів зв’язку та їх технічних характеристик визначаються необхідні види та роди зв’язку і кількість каналів (пропускна спроможність цифрових потоків);

- кількість і важливість ІН визначається оперативною побудовою та завданнями військ (сил), а видів зв'язку (телефонних, відеотелефонних, документальних тощо) на IH - обсягом інформаційного обміну та наявністю і можливостями засобів, комплексів зв’язку.

Враховуючи вищезазначене в статті пропонується оцінювання стійкості С3, РТЗ та АУ проводити за стійкістю кожного IH з подальшим узагальненням для системи у цілому.

Вихідними даними для оцінювання стійкості будь-якого IH є:

1. Основні:

- топологія IH;

- імовірності виживання ліній зв’язку (далі -

ЛЗ) та вузлів зв’язку (далі - В3);

- середній час відсутності зв’язку.

2. Додаткові:

- вид та інтенсивність бойових дій;

- можливості угруповань противника;

- глибина розгортання вузлів зв'язку (далі В3) від лінії бойового зіткнення;

- наявність у противника засобів ураження на визначеній тактичні (оперативній) глибині.

Сучасна С3, РТЗ та АУ ПвК має достатньо розосереджену структуру і тому при оцінювані іï стійкості пропонується ряд обмежень, а саме:

- дії оперативно-тактичних факторів, що впливають на стійкість, а саме живучість, надійність, завадостійкість і кіберстійкість СЗ, РТЗ та АУ, вважаються незалежними;

- стійкість С3, РТЗ та АУ оцінюється через стійкість IН, утворених каналами опорної мережі зв’язку (далі - ОМЗ), лініями прив'язки (далі - ЛПр) до опорних вузлів зв'язку (далі - ОВ3) та (або) лініями прямого зв'язку (далі - ЛПЗ) між вузлами зв’язку пунктів управління (далі - В3 ПУ);

- показник технічної надійності ЛЗ в ході окремої операції (бою) вважається рівним 1;

- в даній методиці не враховується електромагнітна сумісність радіоелектронних засобів;

- навмисні радіозавади та кібернетичні атаки противника не впливають на проводові лінії зв'язку, a їх вплив на радіоканали не порушує зв’язок між вузлами зв'язку в цілому, а призводять до короткочасних перерв зв’язку (хвилини, години);

- забезпечення безпеки кібернетичного простору ЗС України реалізовано шляхом впровадження мережевих засобів захисту - шлюзів безпеки (securitygateway), виробництва лідерів в галузі кібернетич- 
ної безпеки: Cisco, WatchGuard, CheckPoint, DellSonicWall, Fortinet, McAfee.

3 урахуванням прийнятих обмежень вираз (1) буде мати наступний вигляд:

$$
P_{c}=P_{\varkappa},
$$

тобто, стійкість функціонування С3, РТЗ та АУ буде залежати виключно від іiї живучості.

В якості часткових показників оцінювання живучості С3, РТЗ та АУ, в роботі, використовуються:

a) імовірність виживання $\left(P_{6}\right) \mathrm{IH}-$ імовірність того, що в ІН хоча б один маршрут, після впливу противника, буде можливо використовувати для передавання інформації;

б) час відсутності зв'язку $\left(t_{n е p}\right) \mathrm{IH}-$ час, що виникає внаслідок впливу навмисних радіозавад противника та реалізації атак в кібернетичному просторі 3С України.

Критеріями оцінювання живучості С3, РТ3 та АУ є умова:

$$
P_{6} \geq P_{63}, \quad t_{n e p} \leq t_{n 3},
$$

де $P_{63}$ - задана імовірність виживання $\mathrm{IH}$;

$t_{n з}-$ допустимий час відсутності зв'язку на IH.

Задані імовірності виживання та допустимий час відсутності зв'язку на IH на сьогодні жодним нормативним документом не встановлено, що обумовлює необхідність проведення додаткових досліджень, які лежать поза межами цього дослідження. Дане завдання може бути реалізовані за результатами статистичної обробки даних стану зв'язку, що ведеться черговим зі зв'язку, в ході навчань, тренувань, а також при виконанні завдань за призначенням підрозділами та військовими частинами зв'язку (зв’язку та РТЗ).

В межах даного дослідження, пропонується вважати, що імовірність виживання $\left(P_{b}\right)$ IН повинна наближуватися до максимального значення, а час відсутності зв’язку $\left(t_{n е p}\right) \mathrm{IH}$ - до мінімального значення.

Для обчислення показників живучості IH може бути використаний метод еквівалентних топологічних перетворень [7-8]. Враховуючи, що ІН можуть бути представлені у вигляді паралельнопослідовного з'єднання В3 та ЛЗ, повна група перетворень буде містити тільки паралельні й послідовні перетворення.

Розрахункові співвідношення для цих перетворень, щодо імовірності виживання й часу перерви зв’язку за умови незалежності виходу з ладу В3 та Л3 наступні [7-8]:

а) при послідовному з'єднанні:

- імовірність виживання еквівалентної ЛЗ $P_{6}^{л 3} E$, яка утворюється в результаті перетворення визначається за виразом:

$$
P_{b}^{Л 3} E=\sum_{i=1}^{m-1} P_{b} / 3_{i} \sum_{i=2}^{m-1} P_{b}^{63_{i}},
$$

де $P_{b}^{л 3_{i}}$ - імовірність виживання $i$-ї ЛЗ;

$P_{6}^{63_{i}}$ - імовірність виживання $i$-го В3;

m - кількість послідовно з'єднаних В3, Л3.

Час відсутності зв'язку на еквівалентній ЛЗ $t_{n e p}^{л 3 E}$, яка утворюється в результаті перетворення:

$$
t_{n e p}^{\pi 3 E}=t_{c}^{\pi 3 E} \frac{1-P_{B}^{ת 3} E}{P_{B}^{\pi 3} E},
$$

де $t_{c}^{л 3} E$ - середній час відсутності зв'язку на еквівалентній Л3:

$$
t_{c}^{л 3 E}=\left(\sum_{i=1}^{m-1} \frac{1}{t_{c} 3_{i}}+\sum_{i=2}^{m-1} \frac{1}{t_{c}^{B 3_{i}}}\right)^{-1},
$$

де $t_{c}^{л з_{i}}$-середній час відсутності зв’язку на $i$-ій Л3:

$$
t_{c}^{л 3_{i}}=t_{n e p} 3_{i} \frac{P_{6}^{ת 3_{i}}}{1-P_{6}^{\pi 3_{i}}},
$$

де $t_{n e p}^{л 3_{i}}$ - час відсутності зв’язку на $i$-й Л3;

$t_{c}^{63_{i}}$ - середній час відсутності зв'язку на i -мy B3:

$$
t_{c}^{63_{i}}=t_{n e p}^{63_{i}} \frac{P_{b}^{63_{i}}}{1-P_{b}^{63_{i}}},
$$

де $t_{\text {nep }}^{83_{i}}$ - час відсутності зв'язку на $i$-ому В3.

Враховуючи вирази (4; 6-8), вираз (5) матиме наступний вигляд:

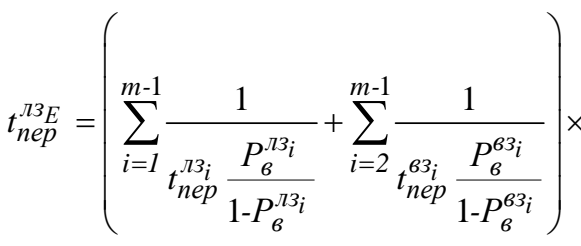

$$
\begin{aligned}
& \times \frac{1-\left(\sum_{i=1}^{m-1} P_{b}^{ת 3_{i}} \sum_{i=2}^{m-1} P_{b}^{63_{i}}\right)}{\sum_{i=1}^{m-1} P_{b}^{\pi 3_{i}} \sum_{i=2}^{m-1} P_{b}^{63_{i}}} .
\end{aligned}
$$

б) при паралельному з'єднанні:

$P_{6}^{л 3} E$ - імовірність виживання еквівалентної Л3, яка утворюється в результаті перетворення:

$$
P_{b}^{\pi 3} E=1-\sum_{i=1}^{n}\left(1-P_{6}^{ת 3_{i}}\right),
$$

де $t_{n e p}^{л 3 E}$ - час відсутності зв'язку на еквівалентній Л3, яка утворюється в результаті перетворення: 


$$
t_{n e p}{ }_{n e p}=\left(\sum_{i=1}^{n} \frac{1}{t_{n e p} 3_{i}}\right)^{-1},
$$

де $n$ - кількість паралельних ЛЗ, що з’єднують два В3.

Для більш повного врахування впливу засобів ураження противника використовуються наступні коефіцієнти:

$K_{6}$ - коефіцієнт ураження каналоутворюючого, вузлового та кінцевого обладнання 3 урахуванням відстані В3 та ЛЗ від ЛБЗ;

$K_{c}-$ коефіцієнт, що враховує інтенсивність ведення бойових, спеціальних, стабілізаційних дій, відповідні значення для нього приводяться в нормативних документах, крім того, цей коефіцієнт враховує сценарії загроз воєнній безпеці України:

- повномасштабна збройна агресія;

- окрема спеціальна операція із застосуванням військових підрозділів;
- блокада морських портів (морського узбережжя) або повітряного простору;

- збройний конфлікт в середині держави (інспірований) та на державному кордоні;

- терористичні акти на території або проти громадян [10].

$K_{y}$ - коефіцієнт наявності у противника необхідних засобів ураження (при відсутності даних дорівнює одиниці).

Розраховані значення імовірності виживання $\left(P_{B}\right)$ IH необхідно перемножити на коефіцієнти $K_{6} K_{c} K_{y}$, а час відсутності зв'язку $\left(t_{n e p}\right)$ на $\mathrm{IH}-$ на їх обернені значення $1 / \kappa_{b} 1 / \kappa_{c} 1 / \kappa_{y}$.

Блок-схема алгоритму оцінювання живучості С3, РТЗ та АУ показана на рис. 1.

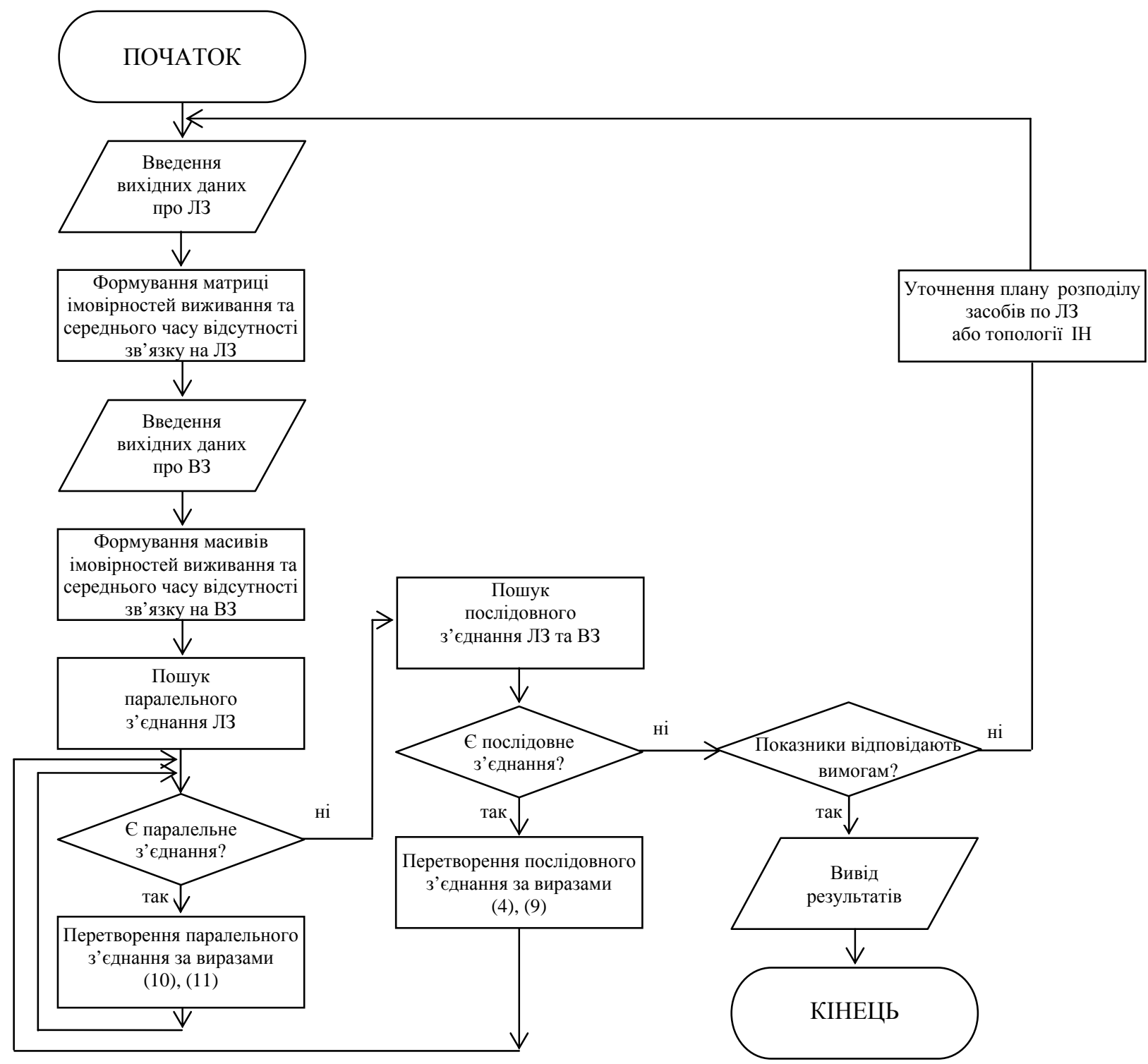

Рис. 1. Блок-схема алгоритму оцінювання живучості С3, РТЗ та АУ 
Етапи методики:

I етап. Формування вихідних даних у вигляді матриць (масивів) імовірностей виживання та відсутності зв’язку для В3 та ЛЗ.

Проведення відповідних розрахунків та підготовка формулярів 3 вихідними даними. Вони готуються на основі даних про топологію IН та розвідувальних даних про противника.

Для підготовки розрахунків повинні бути визначені позивні кінцевих В3 (В3 ПУ), ІН (ЛЗ та В3, що їх формують) і заповнені два формуляри: Формуляр № 1 (табл. 1), Формуляр № 2 (табл. 2).

Таблиця 1

Формуляр № 1 Вихідних даних для оцінювання живучості ЛЗ на IH

\begin{tabular}{|c|c|c|c|}
\hline \multicolumn{2}{|c|}{ Лінійна ділянка } & \multirow{2}{*}{$\begin{array}{c}\text { Тип лінї } \\
\text { зв’язку }\end{array}$} & \multirow{2}{*}{$\begin{array}{c}\text { Протяж- } \\
\text { ність лінії } \\
\text { зв’язку (км) }\end{array}$} \\
\hline $\begin{array}{l}\text { Позивний } \\
\text { В3 (ОВ3) }\end{array}$ & $\begin{array}{c}\text { Позивний } \\
\text { В3 (ОВ3) }\end{array}$ & & \\
\hline & & & \\
\hline
\end{tabular}

Таблиця 2

Формуляр № 2 Вихідних даних для оцінювання живучості В3 IH

\begin{tabular}{|c|c|c|}
\hline Позивний В3 & $\begin{array}{c}\text { Імовірність } \\
\text { виживання В3 }\end{array}$ & $\begin{array}{c}\text { Середній час } \\
\text { відсутності } \\
\text { зв'язку }\end{array}$ \\
\hline & & \\
\hline
\end{tabular}

У формулярі №1 для кожної лінійної ділянки послідовно по графах записуються:

- позивні В3 (ОВ3), що утворять лінійну ділянку;

- тип ЛЗ, що з’єднує пари В3 (ОВ3) лінійної ділянки;

- довжина ЛЗ лінійної ділянки.

Для забезпечення можливості резервування пам’яті під формуляр № 1, потрібно ввести кількість рядків формуляра й значення максимальних довжин (у символах) позивних В3 (ОВ3) і типів Л3. 3 використанням даних першої та другої граф формуляра № 1 формується масив позивних В3 (ОВ3) і матриця кількості ЛЗ на лінійних ділянках. Елементи матриці - кількість Л3, які безпосередньо з'єднують кожну пару В3 (ОВ3) лінійної ділянки. Елементи головної діагоналі матриці дорівнюють нулю. При відсутності безпосереднього зв’язку між будь-якою парою В3 (ОВ3) у відповідній комірці матриці записується знак “тире”.

У формулярі № 2 для кожного ОВ3 ІН послідовно по графах вказуються:

- позивний В3;

- імовірність виживання В3;

- середній час відсутності зв’язку на В3 у заданому IH.

Відповідно до формулярів №№ 1 та 2 формуються матриці (масиви).
При формуванні матриць (масивів) повинні використовуватися таблиці ймовірностей виживання i середнього часу відсутності зв'язку на IH, що виступають у якості постійних вихідних.

Крім того, повинні враховуватися уточнюючі коефіцієнти.

II етап. Еквівалентні топологічні перетворення IH.

По сформованим матрицям (масивам) в процесі роботи по заданому алгоритму проводяться паралельні й послідовні еквівалентні топологічні перетворення для кожного IH.

На початку необхідно перевірити наявність у матриці ЛЗ між парами В3 (ОВ3), які безпосередньо з'єднані двома й більшим числом ЛЗ, та встановити їх кількість.

Кожна така пара В3 (OB3) заміняється парою, з'єднаною однією еквівалентною ЛЗ, імовірність виживання й час відсутності зв'язку якої розраховуються по формулах (10) та (11) відповідно.

Після виконання всіх паралельних перетворень або при відсутності в матриці Л3 між парами В3 (OB3), які з'єднані двома й більшим числом Л3, здійснюється перехід до пошуку послідовних ділянок на IH.

Послідовна ділянка це три В3 (ОВ3), що з'єднані між собою двома Л3, а її проміжним вузлом не може бути один $з$ кінцевих В3 ІН. Послідовне перетворення зазначеної ділянки зводиться до видалення проміжного ОВ3 і з'єднанню між собою В3 (ОВ3) еквівалентною ЛЗ.

Імовірність виживання й середній час відсутності зв'язку якої розраховуються по співвідношеннях (4) та (9) відповідно.

Після послідовного перетворення всіх послідовних ділянок здійснюється перехід до пошуку в матриці кількості Л3 між парами В3 (ОВ3), з'єднаних двома й більшим числом ЛЗ.

Коли в ІН залишаються тільки два кінцевих В3 (В3 ПУ), згортка ІН закінчується, за даним результатом отримується імовірність виживання IH й час відсутності зв’ язку в ІН.

III етап. Уточнення плану розподілу засобів по лЗ або топології IH.

Якщо отримане в результаті розрахунків значення будь-якого показника стійкості не задовольняє визначеним вимогам, то повинен коректуватися план розподілу засобів по ЛЗ, або ж топологія ІН.

Після корекції проводиться розрахунок за етапами I та II.

Оцінювання стійкості С3, РТ3 та АУ закінчується після оцінювання живучості всіх її IH.

Приклад оцінювання живучості одного з IH C3 РТЗ АУ, топології, якого наведена на рис. 2.

Оцінювання проводиться для IН між вузлами зв’язку В3 $3_{1}$ та В3 2 . 


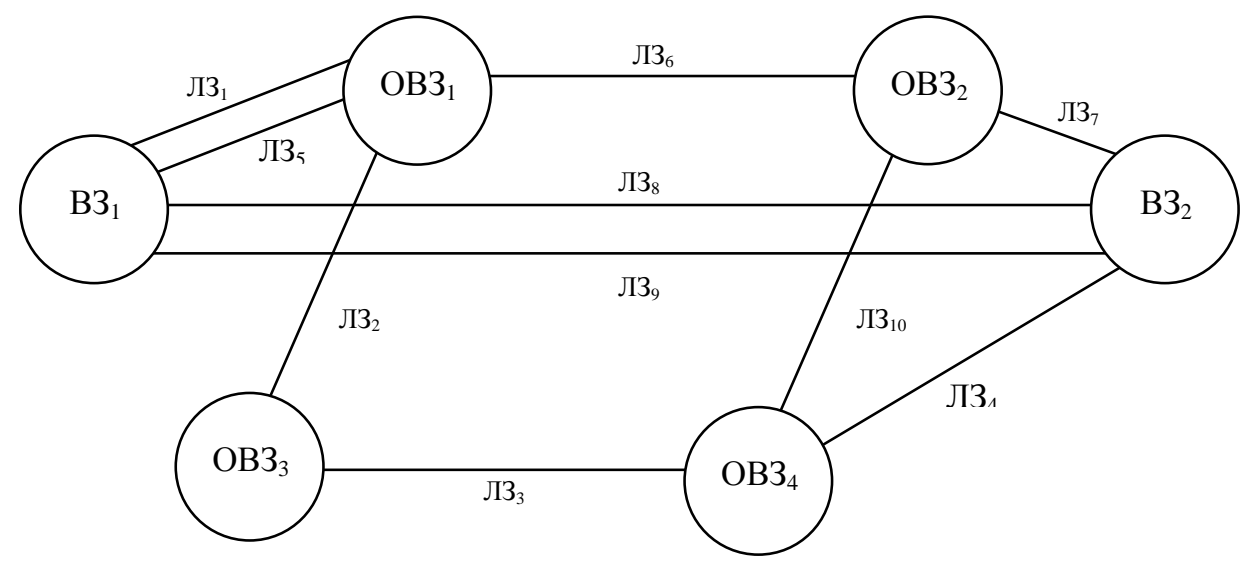

Рис. 2. Топологія IH

Перед початком проведення оцінюванні живучості слід провести маркування всіх утворених ЛЗ між В3, яке можна оформити у вигляді відповідної таблиці (табл. 3).

Таблиця 3

Маркування ЛЗ на IH

\begin{tabular}{|c|c|c|}
\hline \multicolumn{2}{|c|}{ Лінійна ділянка } & \multirow[b]{2}{*}{ Код лінії зв’язку } \\
\hline $\begin{array}{c}\text { Позивний В3 } \\
\text { (ОВ3) }\end{array}$ & $\begin{array}{c}\text { Позивний В3 } \\
\text { (ОВ3) }\end{array}$ & \\
\hline $\mathrm{B} 3_{1}$ & $\mathrm{OB}_{1}$ & Л3 $3_{1}$ \\
\hline $\mathrm{B} 3_{1}$ & $\mathrm{OB}_{1}$ & Л3 $3_{5}$ \\
\hline $\mathrm{OB}_{1}$ & $\mathrm{OB}_{3}$ & Л3 $3_{2}$ \\
\hline $\mathrm{OB}_{3}$ & $\mathrm{OB}_{2}$ & Л3 ${ }_{6}$ \\
\hline $\mathrm{OB}_{3}$ & $\mathrm{OB}_{4}$ & Л3 $3_{3}$ \\
\hline $\mathrm{OB}_{2}$ & $\mathrm{OB}_{4}$ & Л3 ${ }_{10}$ \\
\hline $\mathrm{OB}_{2}$ & $\mathrm{~B}_{2}$ & Л3 \\
\hline $\mathrm{B} 3_{1}$ & $\mathrm{~B} 3_{2}$ & ЛЗ ${ }_{8}$ \\
\hline $\mathrm{B} 3_{1}$ & $\mathrm{~B}_{3}$ & Л3 ${ }_{9}$ \\
\hline $\mathrm{OB}_{3}$ & $\mathrm{~B}_{3}{ }_{2}$ & Л3 $3_{4}$ \\
\hline
\end{tabular}

Постійними вихідними даними при оцінці живучості IH, яку можливо реально забезпечити, $\epsilon$ імовірності виживання й середні часи відсутності зв’язку на ЛЗ, залежно від їхнього типу й довжини.

Змінними вихідними даними є ії топологія, тип, довжина Л3, яка безпосередньо з’єднує кожну пару
В3 (ОВ3), а також імовірності виживання й середні часи відсутності зв’язку на ОВЗ. Змінні вихідні дані оформляються у вигляді формулярів, у відповідності до табл. 3 заносимо дані до формулярів №№ 1 та 2, які набудуть наступного вигляду, формуляр № 1 (табл. 4), а формуляр № 2 (табл. 5).

Таблиця 4

Формуляр № 1 Вихідних даних для оцінювання живучості Л3 на IH

\begin{tabular}{|c|c|c|c|}
\hline \multicolumn{2}{|c|}{$\begin{array}{l}\text { Лінійна } \\
\text { ділянка }\end{array}$} & \multirow{2}{*}{ Тип лінії зв’язку } & \multirow{2}{*}{$\begin{array}{c}\text { Протяжність лінії } \\
\text { зв’язку (км) }\end{array}$} \\
\hline $\begin{array}{c}\text { Позивний В3 } \\
\text { (ОВ3) }\end{array}$ & $\begin{array}{c}\text { Позивний В3 } \\
\text { (ОВ3) }\end{array}$ & & \\
\hline $\mathrm{B} 3_{1}$ & $\mathrm{OB}_{1}$ & ПКЛ-296/302 & 10 \\
\hline $\mathrm{B}_{1}$ & $\mathrm{OB}_{3}$ & $\mathrm{P}-419$ & 10 \\
\hline $\mathrm{OB}_{1}$ & $\mathrm{OB}_{2}$ & $\mathrm{P}-414$ & 30 \\
\hline $\mathrm{OB}_{2}$ & $\mathrm{~B} 3_{2}$ & ПКЛ-296/302 & 10 \\
\hline $\mathrm{B} 3_{1}$ & $\mathrm{~B}_{2}$ & P-417 & 40 \\
\hline $\mathrm{B}_{1}$ & $\mathrm{~B}_{2}$ & $\mathrm{P}-140 \mathrm{M}$ & 10 \\
\hline $\mathrm{OB}_{3}$ & $\mathrm{OB}_{4}$ & ПКЛ-296/302 & 20 \\
\hline $\mathrm{OB}_{3}$ & $\mathrm{OB}_{3}$ & P-419 & 15 \\
\hline $\mathrm{OB}_{2}$ & $\mathrm{OB}_{4}$ & ПКЛ-296/302 & 15 \\
\hline $\mathrm{B}_{2}$ & $\mathrm{OB}_{4}$ & P-419 & 10 \\
\hline
\end{tabular}


Таблиця 5

Формуляр № 2 Вихідних даних для оцінювання живучості В3 IН

\begin{tabular}{|c|c|c|}
\hline Позивний ОВ3 & Імовірність виживання ОВ3 & Середній час відсутності зв’ язку \\
\hline $\mathrm{OB}_{1}$ & 0,7 & 1,8 \\
\hline $\mathrm{OB}_{2}$ & 0,7 & 1,8 \\
\hline $\mathrm{OB}_{3}$ & 0,8 & 2,3 \\
\hline $\mathrm{OB}_{4}$ & 0,8 & 2,3 \\
\hline
\end{tabular}

Приклад розрахунку часткових показників топології IH 3 використанням розрахункооцінювання живучості СЗ, РТЗ та АУ шляхом по- вих співвідношень $\quad(4)-(11)$, показаний слідовно-паралельних еквівалентних перетворень на рис. 3.

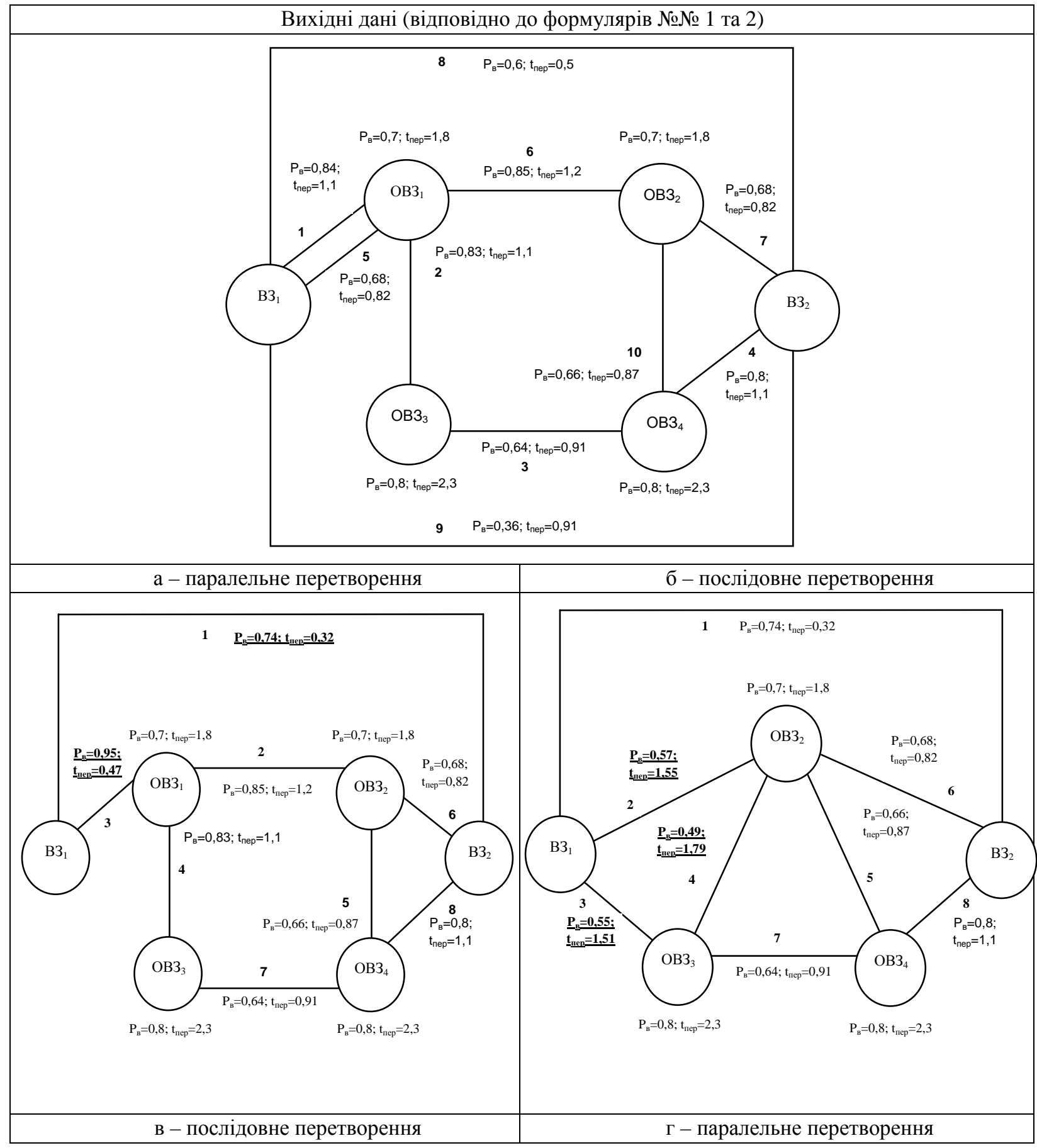

Рис. 3. Приклад розрахунку часткових показників оцінювання живучості С3, РТЗ та АУ (початок) 

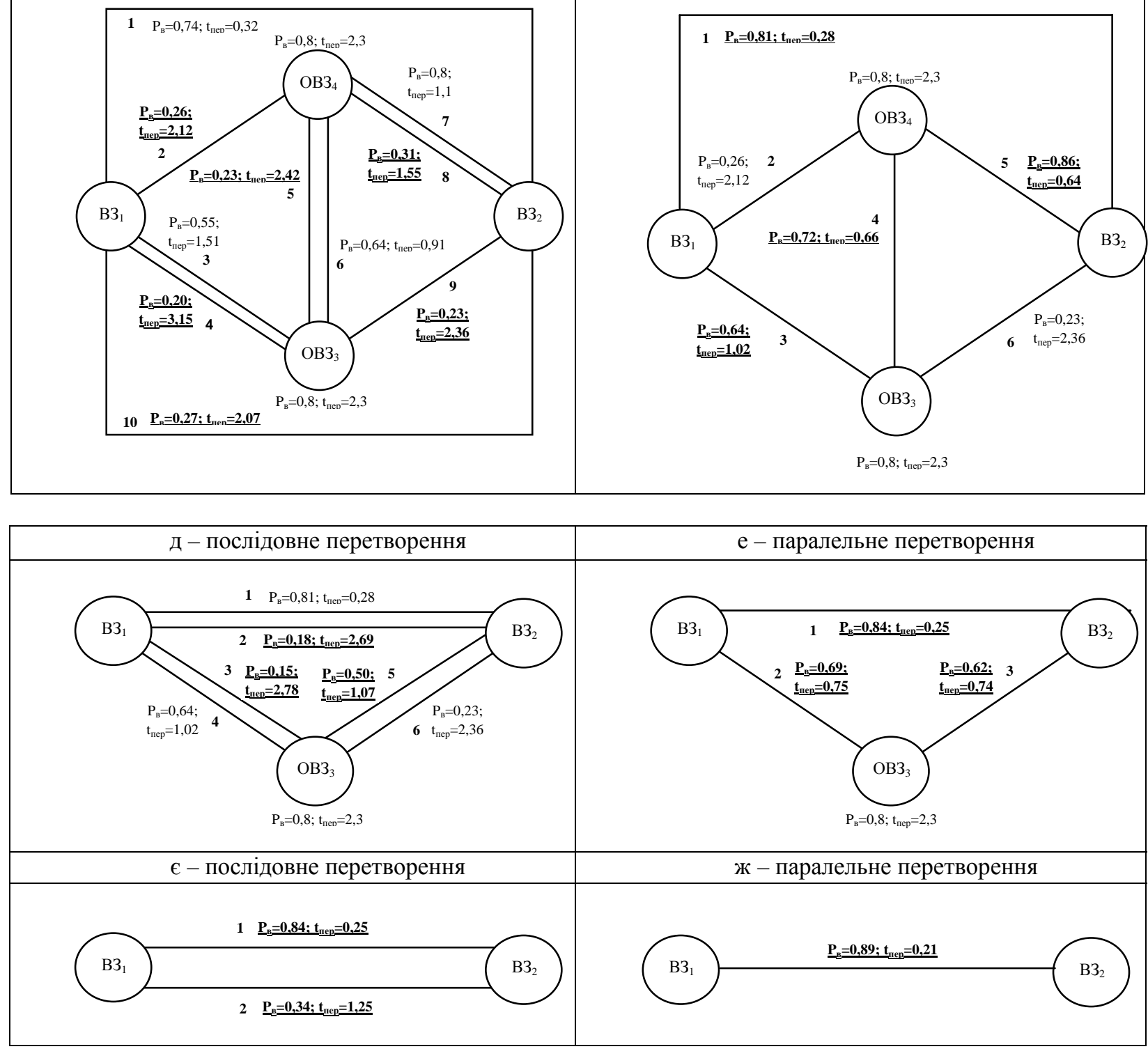

Рис. 3. Приклад розрахунку часткових показників оцінювання живучості С3, РТЗ та АУ (закінчення)

На підставі проведених розрахунків, утворена згортка IH містить гілку між $\mathrm{B} 3_{1}$ та $\mathrm{B} 3_{2}$, для якої $P_{6}=0,89, t_{n e p}=0,21=12,6$ хв., можна вважати, що задана ймовірність виживання IН $P_{63}=0,8$ та заданий час відсутності зв'язку в IH $t_{n 3}=2,3=148$ хв., що буде відповідати максимальним значенням цих величин для ОВ3 IН, та в свою чергу буде відповідати умові (3), а саме:

$$
P_{6} \geq P_{63}, \quad t_{n e p} \leq t_{n 3},
$$

за умови не виконання даної умови виникає необхідність збільшення в топології ІН кількості ЛЗ або В3. При розрахунках декількох варіантів топології $\mathrm{IH}$, до уваги приймається варіант, де імовірність виживання $\left(P_{b}\right) \mathrm{IH}$ досягає максимального значення, а час відсутності зв’язку $\left(t_{n е p}\right) \mathrm{IH}-$ мінімального значення.

\section{Висновки}

Запропоновану методику можливо ефективно використовувати для дослідження та оцінювання стійкості ІН та С3, РТЗ та АУ в цілому в усіх ланках управління, 3 урахуванням вогневого та радіоелектронного впливу противника. Оцінювання стійкості IH може проводитися як у процесі планування, так і в існуючій (розгорнутій) С3, РТЗ та АУ. Для оцінювання стійкості доречно використовувати спеціалізоване програмне забезпечення, яке буде здійснювати відповідні розрахунки за наведеним математичним апаратом моделі розробленої методики. В даній статті для проведення відповідних розрахунків використано програму для роботи 3 електронними таблицями Microsoft Excel. В подальшому необхідно розробляти методики оцінювання якості С3, РТЗ та АУ з урахування інших вимог, що висуваються до С3, РТЗ та АУ. 


\section{Список літератури}

1. Основы теории управления войсками / П.К. Алтухов, И.А. Афонский, И.В. Рыболовский, А.Е. Татарченко. - М.: Воениздат, 1984. - $220 \mathrm{c}$.

2. Щербина Л.П. Основы теории сетей военной связи / Л.П. Щербина. - Л.: ВАС, 1984. - 170 с.

3. Методики по расчету и оценке полевых систем связи // Курс лекций. - Л.: ВАС, 1985.

4. Основные показатели современной операции (боя) и основные оперативно-технические расчеты по связи. - К.: КВВИУС, 1980. - $112 \mathrm{c}$.

5. Чуйко В.А. Методика анализа пропускной способности и живучести элементов системы связи тактического звена управления: дис. ... канд. техн. наук / В.А. Чуйко. - К., 1999. - 232 с.

6. Шевченко В.О. Системний підхід до розроблення методологічних основ дослідження телекомунікаційних мереж військового призначення / В.О. Шевченко // Наука і оборона. - 2004. - № 4. - С. 42-46.

7. Боговик А.В. Эффективность систем военной связи и методы ее оценки / А.В. Боговик, В.В. Игнатов. - СПб.: BAC, 2006. - $152 \mathrm{c}$.

8. Авсюкевич А.Н. Эффективность и электронная защита военных систем связи / А.Н. Авсюкевич, В.Ф. Комарович, М.В. Симонов. - Л.: ВОЛКАС, 1980. - 32 с.

9. Військовий стандарт 01.112.001. Військовий зв’язок. Терміни та визначення. - К., 2006.

10. Указ президента України “Про воєнну доктрину України № 555 від 24 вересня 2015” [Електронний ресурс]. Режим доступу: https://zakon.rada.gov.ua/laws/show/555/2015.

\section{References}

1. Altukhov, P.K., Afonsky, I.A., Rybolovsky, I.V. and Tatarchenko, A.E. (1984), "Osnovy teorii upravleniya vojskami” [Bases of the theory of control of troops], Voenizdat, Moscow, $220 \mathrm{p}$.

2. Shcherbina, L.P. (1984), “Osnovy teorii setej voennoj svyazi” [Fundamentals of Theory of Military Communication Networks], MCA, Leningrad, 170 p.

3. (1985), "Metodiki po raschetu i ocenke polevyh sistem svyazi” [Methods for calculation and evaluation of field communication systems], Course of lectures, MCA, Leningrad.

4. (1980), "Osnovnye pokazateli sovremennoj operacii (boya) i osnovnye operativno-tehnicheskie raschety po svyazi” [Basic indicators of modern operation (battle) and basic operational and technical calculations on communication], KVIUS, Kyiv, 112 p.

5. Chuiko, V.A. (1999), "Metodika analiza propusknoj sposobnosti i zhivuchesti elementov sistemy svyazi takticheskogo zvena upravleniya" [A technique for analyzing the bandwidth and survivability of elements of the tactical link control system], Kyiv, 232 p.

6. Shevchenko, V.A. (2004), "Sistemnij pidhid do rozroblennya metodologichnih osnov doslidzhennya telekomunikacijnih merezh vijskovogo priznachennya” [System approach to the development of methodological bases for the study of military telecommunication networks], Science and Defense, No. 4, pp. 42-46.

7. Bogovik, A.V. and Ignatov, V.V. (2006), "Effektivnost sistem voennoj svyazi i metody ee ocenki” [Efficiency of military communication systems and methods of its evaluation], MCA, Saint Petersburg, pp. 151-152.

8. Avsjukevich, A.N., Komarovich, V.F. and Simonov, M.V. (1980), "Effektivnost i elektronnaya zashita voennyh sistem svyazi” [Efficiency and electronic protection of military communication systems], MCA, Leningrad, pp. 29-32.

9. Military Standard (2006), “01.112.001. Vijskovij zv’yazok. Termini ta viznachennya” [01.112.001. Military Communication. Terms and definitions], Kyiv.

10. Decree of the President (2015), “Pro voyennu doktrinu Ukrayini № 555 vid 24.09.2015” [On the Military Doctrine of Ukraine No. 555 dated 24.09.2015], available at: www.zakon.rada.gov.ua/laws/show/555/2015.

Надійшла до редколегії 04.02.2020 Схвалена до друку 10.03.2020

\section{Відомості про авторів:}

\author{
Кас'яненко Максим Вікторович \\ кандидат військових наук \\ заступник начальника кафедри \\ Національного університету оборони \\ України ім. І. Черняховського, \\ Київ, Україна \\ https://orcid.org/0000-0002-3749-4441
}

\section{Маляр Вячеслав Анатолійович}

слухач Національного університету оборони

України ім. І. Черняховського,

Київ, Україна

https://orcid.org/0000-0003-3688-5093

\section{Information about the authors:}

\author{
Maksym Kasianenko \\ Candidate of Military Sciences \\ Deputy Head of the Department \\ The National Defense University \\ of Ukraine named after Ivan Cherniakhovskyi, \\ Kyiv, Ukraine \\ https://orcid.org/0000-0002-3749-4441
}

\section{Viacheslav Maliar}

Postgraduate Student of Ivan Chernyakhovsky

National Defense University of Ukraine,

Kyiv, Ukraine

https://orcid.org/0000-0003-3688-5093 
Бондар Свгеній Анатолійович

слухач Національного університету оборони

України ім. І. Черняховського,

Київ, Україна

https://orcid.org/0000-0001-9252-7501

\section{Павленко Максим Анатолійович}

доктор технічних наук професор начальник кафедри

Харківського національного університету

Повітряних Сил ім. І. Кожедуба,

Харків, Україна

https://orcid.org/0000-0003-3216-1864
Yevhenii Bondar

Postgraduate Student of Ivan Chernyakhovsky

National Defense University of Ukraine,

Kyiv, Ukraine

https://orcid.org/0000-0001-9252-7501

\section{Maxim Pavlenko}

Doctor of Technical Sciences Professor Head of Department

of Ivan Kozhedub Kharkiv

National Air Force University,

Kharkiv, Ukraine

https://orcid.org/0000-0003-3216-1864

\title{
МЕТОДИКА ОЦЕНКИ УСТОЙЧИВОСТИ СИСТЕМЫ СВЯЗИ, РАДИОТЕХНИЧЕСКОГО ОБЕСПЕЧЕНИЯ И АВТОМАТИЗАЦИИ УПРАВЛЕНИЯ ВОЗДУШНОГО КОМАНДОВАНИЯ
}

\author{
М.В. Касьяненко, В.А. Маляр, Е.А. Бондар, М.А. Павленко
}

Анализ опыта войн и вооруженных конфликтов свидетельствует о том, что максимальная реализация боевых возможностей воздушного командования во многом зависит от наличия устойчивого, непрерывного, оперативного и скрытого управления. Такое управление может быть достигнуто только при построении высокоэффективной, многоуровневой системы управления, функционирование которой, объективно, зависит от эффективности функционирования подсистемы связи, радиотехнического обеспечения и автоматизации управления. Однако, опыт применения сил и средств связи, радиотехнического обеспечения и автоматизированного воздушного командования в ходе антитеррористической операчии на востоке Украины свидетельствует о том, что система связи, радиотехнического обеспечения и автоматизачии управления вследствие ряда причин, не в полной мере удовлетворяет потребности органов управления. Среди таких причин, основной следует считать - ее недостаточную устойчивость. Поэтому, возникает насущная необходимость в проведении научных исследований с иелью обеспечения ее устойчивости на необходимом уровне. Вопросу оценки устойчивости системы связи, радиотехнического обеспечения и автоматизации управления посвящен ряд научных трудов. Однако их анализ показал, что они, по тем или иным причинам, не могут быть в полной мере использованы для оценки устойчивости системы связи, радиотехнического обеспечения и автоматизации управления в современных условиях ведения боевых действий. В статье предложена методика, которая в отличие от известных, основывается на методе эквивалентных топологических преобразований, что позволило более адекватно описать проиесс функиионирования системы в современных условиях ведения боевых действий. Разработка данной методики проведен с обоснованием модели системы, определения ограничений и порядка подготовки исходных данных. Представлен алгоритм оченки устойчивости информационных направлений по определенным показателям и критериям. Сформулированы предложения по практической реализачии разработанной методики в виде специализированного программного обеспечения. Обозначены перспективы дальнейших исследований. Основными методами исследования, использованные при его проведении были методы анализа, синтеза и эквивалентных топологических преобразований.

Ключевые слова: система связи, радиотехнического обеспечения и автоматизачии управления, устойчивость системы связи, радиотехнического обеспечения и автоматизации управления, живучесть системы связи, радиотехнического обеспечения и автоматизации управления, информационное направление, узел связи, линия связи.

\section{ASSESSMENT METHOD OF COMMUNICATION SYSTEM'S SUSTAINABILITY, RADIOTECHNICAL SUPPLY AND AUTOMATION OF AIR COMMAND CONTROL}

\section{Kasianenko, V. Maliar, Ye. Bondar, M. Pavlenko}

An analysis of the wars experience and armed conflicts shows that the maximum realization of combat capabilities of the air command in full largely depends on the presence of stable, continuous, operational and covert control. Such control can only be reached by building a highly efficient, multi-level control system, the functioning of which depends, objectively, on the performance of the communication subsystem, radio equipment and control automation. However, the experience of using forces and means of communication, radio-technical support and automated control of air command, in the course of anti-terrorist operation in the east of Ukraine shows that the system of communication, radio-technical support and automation of control for a number of reasons does not fully meet the needs governing bodies. Among these reasons, the main reason is to consider its lack of stability. Therefore, there is an urgent need for research to ensure its sustainability at the required level. A number of scientific papers are devoted to the evaluation of communication system stability, radio equipment and automation control. However, their analysis showed that, for one reason or another, they could not be fully used to evaluate the stability of the communications system, radio equipment and automation of control in modern combat conditions. The article proposes a technique, which, unlike the known ones, is based on the method of equivalent topological transformations, which allowed to describe more adequately the process of functioning of the system in modern conditions of warfare. The development of this methodology was carried out with the justification of the model of the system, determination of limitations and order of preparation of the initial data. The algorithm of information of stability of estimation directions according to certain indicators and criteria is presented. Suggestions for practical implementation of the developed methodology in the form of specialized software are formulated. Prospects for further research are outlined. The main research methods used in its implementation were methods of analysis, synthesis and equivalent topological transformations.

Keywords: communication, radio engineering and control automation, the robustness of the communications, radio and control automation systems, the survivability of communications, radio, and automation controls, information direction, the communication node, communication line. 